\title{
CXCR-4 and COX-2 Expression in Basal Cell Carcinomas and Well-Differentiated Squamous Cell Carcinomas of the Skin; Their Relationship with Tumor Invasiveness and Histological Subtype
}

\author{
Bazal Hücreli Karsinomlar ve İyi Differansiye Skuamöz Hücreli \\ Karsinomlarda CXCR-4 ve COX-2 Ekspresyonu; Bunların Tümör İnvazivliği \\ ve Histolojik Subtip ile İlişkileri
}

\author{
Oya Nermin SivRiKOZ', Belkız UYAR², Filiz DAĞ${ }^{3}$, Funda TAŞLI', Salahattin M. SANAL ${ }^{4}$ \\ Department of 'Pathology and ' ${ }^{2}$ Dermatology, Şifa University, Faculty of Medicine, IZMIR, TURKEY, \\ Department of ${ }^{3}$ Pathology and ${ }^{4}$ Oncology, Tinaztepe Private Hospital, IZMIR, TURKEY
}

\begin{abstract}
Objective: Both CXCR-4 and COX-2 are biological markers that play a significant role in several neoplastic processes. We explored the differences in expression of these markers in certain subtypes of basal cell carcinoma, and squamous cell carcinomas in general.

Material and Method: In this study, we investigated the differences between 38 patients with basal cell carcinoma (nodular, infiltrative and micro-nodular subtypes) and 24 patients with well-differentiated squamous cell carcinomas with respect to their depth of invasion, tumor location, age, and CXCR-4 and COX-2 expression.

Results: Statistically, we found no significant difference between squamous cell carcinomas and basal cell carcinoma in terms of CXCR-4 and COX-2 expression; however, the degree of marker expression became stronger with increasing depth of invasion in both tumors. The expression of both markers was also higher in infiltrative type basal cell carcinoma compared to all the other subtypes. The results were statistically significant $(\mathrm{p}<0.05)$. Additionally, a significantly positive correlation also existed between COX2 and CXCR4 expression $(\mathrm{p}<0.05)$.

Conclusion: The degree of expression of CXCR-4 and COX-2 is related to invasiveness in both malignancies; thus, infiltrative type of basal cell carcinoma displays the highest degree of CXCR-4 and COX-2 expression among all the subtypes. Furthermore, our results indicate that these two biological markers may both be involved in the process of carcinogenesis and require investigation with further molecular and genetic studies in larger series.
\end{abstract}

Key Words: CXCR-4, COX-2, Basal cell carcinoma, Squamous cell carcinoma, Skin neoplasms

\section{ÖZ}

Amaç: CXCR-4 ve COX-2 birçok neoplastik süreçte rol oynayan biyolojik belirleyicilerdir. Bazal hücreli karsinom ve skuamöz hücreli karsinomlarda bu belirleyicilerin ekspresyonlarındaki farkları araştırıldi.

Gereç ve Yöntem: Bu çalışmada, 38 bazal hücreli karsinom (noduler, infiltratif ve mikronodüler subtipler) ve 24 iyi diferansiye skuamöz hücreli karsinom hastasında invazyon derinliği, tümör lokasyonu, yaş, CXCR-4 ve COX-2 ekspresyonu arasındaki ilişki araştırıldı.

Bulgular: İstatistiksel olarak, CXCR-4 ve COX-2 ekspresyonunda, skuamoz hücreli karsinom ve bazal hücreli karsinom arasında önemli bir fark saptanmadi. Bununla beraber, her iki tümörde de invazyon derinliği arttıkça ekspresyon derecesinin arttığı saptandı. İnfiltratif tip bazal hücreli karsinomda, diğer subtiplere kıyasla bu iki belirleyicinin ekspresyonu daha yüksekti . Sonuçlar istatistiksel olarak anlamlı idi $(\mathrm{p}<0,05)$. Ayrica COX-2 ve CXCR-4 ekspresyonları arasında kuvvetli pozitif korelasyon saptand $1(\mathrm{p}<0.05)$.

Sonuç: Her iki tümörde de, CXCR-4 ve COX-2 ekspresyonunun derecesi invazivlikle ilişkilidir; bununla birlikte, infiltratif tip bazal hücreli karsinom, tüm subtipler içinde en yüksek derecede CXCR-4 ve COX-2 ekspresyonu gösterir. Ek olarak bulgularımız, bu iki belirleyicinin herbirinin tümör invazyonu ile ilişkisinden dolayı, karsinogeneziste ikisinin ilișkili olabileceğini ve daha büyük serilerde genetik ve moleküler çalışmalarla araştırılması gerektiğini düşündürmektedir.

Anahtar Sözcükler: CXCR-4, COX-2, Bazal hücreli karsinom, Skuamöz hücreli karsinom, Deri tümörleri 


\section{INTRODUCTION}

The most common types of non-melanoma skin carcinomas are basal cell carcinoma (BCC) and squamous cell carcinoma (SCC) $(1,2)$. UV light exposure plays an important role in the etiology of both tumors (3). While SCC has significant metastatic potential, BCC rarely metastasizes.

BCCs are histologically classified as superficial, nodular, micronodular, infiltrative, nodulocystic, fibroepithelioma like, metatypical, and mixed types. The micronodular and infiltrative types tend to show local recurrence more frequently than the others and have a higher potential to metastasize (4). Superficial and metatypical BCCs also have increased rate of recurrence.

In general, SCC has a more aggressive behavior than BCC. SCC often metastasizes to neighboring lymph nodes and distant organs. Currently, convincing scientific information demonstrates that chemo-attractants, like CXCR-4, secreted by stromal immune cells, enable cancer cells invade tissues where they have secondary growth potential (5).

Chemokines are structurally 8-14 kDa sized polypeptides that have the properties of a signaling molecule. CXCR-4 is a member of chemokine receptor family. The interaction between CXCR-4 and stromal cell-derived factor (SDF$1 \alpha)$, its ligand, is known to play an important role in tumorigenesis, metastasis, and angiogenesis (6-8). This biological role is demonstrated frequently in lung, breast, melanoma, glioblastoma, pancreatic and cholangiocellular carcinomas (9-13).

Lately, UV-induced abnormal prostaglandin synthesis is reported to be an important factor in the development of cancer. COX is an enzyme that catalyses the conversion of free arachidonic acid to prostaglandins. It has two isoforms known as COX-1 and COX-2. COX-1 is found in most normal tissues and is required for normal physiological function (14). COX-2 is not detected under normal conditions and is expressed in circumstances such as growth factors, cytokines, oncogene activation and hypoxia. COX-2 is also known to be expressed in many neoplastic processes. It has been found to stimulate cell division, angiogenesis, and inhibit apoptosis $(15,16)$.

We investigated the importance of CXCR-4 and COX2 expression in both BCC and SCC. Furthermore, we examined if these biological markers showed any difference with respect to degree of invasiveness in each BCC subtype, which recently has been found to play a significant role in the development of metastatic process.

\section{MATERIALS and METHODS}

A total of 62 patients consisting of 24 SCC and 38 BCC were evaluated in our study. Clinical information of all cases (age, gender and tumor site) was obtained from the hospital records. Paraffin blocks of each patient were obtained from the archival tissues. Sections (4 micron thick) were taken from the paraffin blocks, one for H\&E staining and two for immunohistochemical staining on two $(+)$ charged slides. H\&E-stained profiles were evaluated under the light microscope. Basal cell carcinomas were divided into two groups as aggressive (infiltrative, micronodular) and nonaggressive (nodular). All SCCs were well differentiated and all were invasive. The other types of basal cell carcinoma and poorly- and moderately-differentiated squamous cell carcinomas were excluded from the study because of their limited number for analysis. All cases of SCCs were the well-differentiated, keratinized type. None had any lymph node or distant organ metastasis.

The positive charged slides were stained with DAKO Autostainer 48 Link (Dako, Denmark) and COX-2 (DAKO, Clone CX-294, 1/100 dilution) and CXCR-4 (Abcam, Clone ab 2074, 1/50 dilution) antibodies. The slides were then evaluated under the light microscope by two pathologists. Cytoplasmic staining in both was accepted as positive and was scored as follows: $0=$ no staining, $1+: 1-25 \%$ cells $(1+$ : Poor staining), $2+: 26-50 \%$ cells, $3+: 51-100 \%$ cells $(2+, 3+$ : strong staining).

Statistical method: The Statistical Package for the Social Sciences (SPSS) 21 and Medcalc 9 (Acacialaan 22, B-8400 Ostend, Belgium) programs were utilized for data analysis. For analysis of quantitative data, compliance with the normal distribution was evaluated with the KolmogorovSmirnov test, Shapiro-Wilk test and Variation coefficients. Parametric methods were used for the analysis of variables with a normal distribution and nonparametric methods were used for the analysis of variables without a normal distribution. The Independent Samples t- test was used in the comparison of two independent groups and the OneWay Anova test in the comparison of multiple groups with each other. The Pearson Chi-Square and Linear-by-Linear Association tests were used for the comparison of categorical data. Data were examined at the $95 \%$ confidence level and $p$ values smaller than 0.05 were accepted as significant.

\section{RESULTS}

There were 62 patients consisting of 38 (61.3\%) BCC and 24 (38.7\%) SCC cases. The ages of the cases varied between 41 and 91 the mean age was 72 years. Among BCC patients, 19 were male and 19 female. According to histological 
subtype, they were distributed as 27 nodular, 7 infiltrative and 4 micronodular. Among SCC patients, there were 17 male and 7 female patients.

The anatomic distribution of both malignancies were as follows: Among SCC patients, the malignancy arose from facial structures in $12(50.0 \%)$, from the ear in $2(8.3 \%)$, and from the trunk in 5 (20.8\%) whereas among BCC patients the malignancy arose from the facial structures in $26(68.4 \%)$, from the scalp in $3(7.9 \%)$, from the ear in $4(10.5 \%)$, and from the trunk in $5(13.2 \%)$. Statistically no significant relationship was found between tumor type, location, patient age and CXCR- 4 as well as COX-2 $(\mathrm{p}>0.05)$.

Among BCC patients, COX-2 staining was absent in 57.9\%, poor $(+1)$ in $15.8 \%$, and strong $(+2,+3)$ (Figure 1) in $36.3 \%$. All patients with infiltrative subtype stained strongly positive, while none showed absent or weak staining. The multinodular subtypes showed absent or poor staining in $75 \%$ and strong staining in only $25 \%$. The staining was absent or poor in $92.6 \%$ of the nodular subtype cases. Strong staining was observed in only $7.4 \%$. These differences were statistically significant $(\mathrm{p}<0.05)$. When cases were distributed between aggressive and non-aggressive groups, $27.2 \%$ of cases in the aggressive group showed either absence of staining or at the most poor staining properties while $72.8 \%$ showed strong positivity. In the non-aggressive group $92.6 \%$ showed absence or poor staining characteristics. Only 7.4\% of cases in the non-aggressive group showed strong staining properties $(\mathrm{p}<0.05)$

COX-2 staining was absent or poor (+1) (Figure 2) in 50\% of the SCC cases and strong in 50\%. Among the BCC cases, $36.6 \%$ stained strongly positive. However, when staining

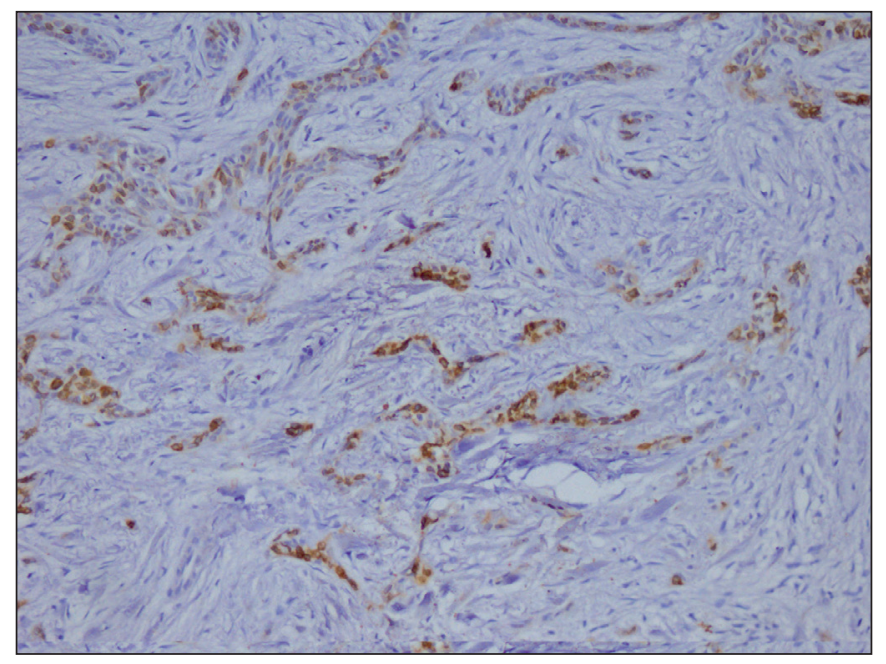

Figure 1: Basal cell carcinoma, 3+ staining (COX-2; x40). characteristics were compared between the histological types, $42.1 \%$ of SCCs stained positively whereas, when the presence $(1+$ to $3+)$ or complete absence $(0)$ of any staining was taken into consideration, $84.6 \%$ of the BCC cases stained positively. The difference between the staining characteristics of these two histologies was not statistically significant.

When COX-2 staining was evaluated according to depth of invasion in BCC cases, there was no staining in cases with papillary dermis invasion and 4 cases with reticular dermis invasion. The staining was absent in $77.8 \%$, poor in $16.7 \%$, and strong in only $5.6 \%$. Strong staining was present in $75 \%$ of the cases with fat and deeper tissue invasion (Table I). The results were statistically significant $(\mathrm{p}<0.05)$.

When COX-2 staining properties were investigated in SCC cases, there was absence of staining or at the most poor staining in all of the cases with papillary dermis invasion. In cases with reticular dermis invasion, $40 \%$ showed absence or poor staining properties; whereas, in cases with subcutaneous fat or deep dermis invasion, $87.5 \%$ showed strong staining properties.

Among SCC patients, CXCR-4 staining was absent or poor $(0,+1)$ (Figure 3$)$ in $45.8 \%$ and strong $(+2,+3)$ (Figure 4$)$ in $54.1 \%$. There was no statistically significant difference ( $p>0.05)$. Furthermore, again among BCC patients, CXCR4 staining was absent or poor $(0,+1)$ in $68.4 \%$ and strong (Figure 5) in $31.6 \%$. With respect to the relationship between BCC tumor subtypes and CXCR-4 staining characteristics, $14.3 \%$ of infiltrative types were poorly stained or none at all, and $85.7 \%$ were strongly stained. Micronodular types showed 0 and +1 staining in $75.0 \%$ and strong positivity in $25.0 \%$. The nodular types showed absent or poor staining in

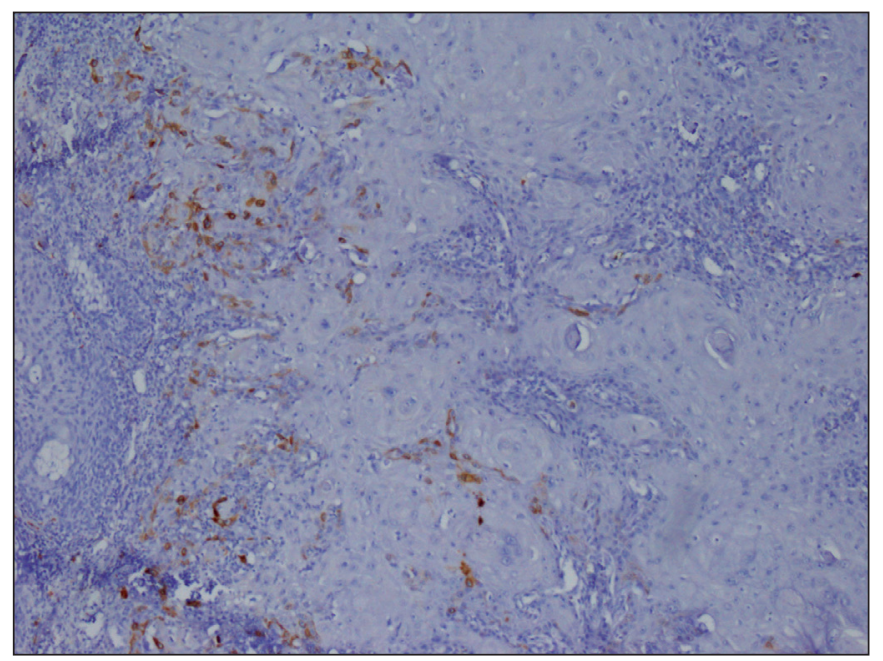

Figure 2: Squamous cell carcinoma, $1+$ staining (COX-2; $\mathrm{x} 40$ ). 
Table I: COX-2 distribution by invasion in basal cell carcinomas

\begin{tabular}{|c|c|c|c|c|c|c|c|c|}
\hline \multirow{3}{*}{ Invasion depth } & \multicolumn{8}{|c|}{$\begin{array}{c}\text { Basal Cell Carcinoma } \\
\text { Cox-2 }\end{array}$} \\
\hline & \multicolumn{2}{|c|}{ No staining } & \multicolumn{2}{|r|}{$1+$} & \multicolumn{2}{|r|}{$2+$} & \multicolumn{2}{|r|}{$3+$} \\
\hline & $\%$ & $\begin{array}{l}\text { Number of } \\
\text { patients (n) }\end{array}$ & $\%$ & $\begin{array}{l}\text { Number of } \\
\text { patients (n) }\end{array}$ & $\%$ & $\begin{array}{l}\text { Number of } \\
\text { patients (n) }\end{array}$ & $\%$ & $\begin{array}{l}\text { Number of } \\
\text { patients (n) }\end{array}$ \\
\hline $\mathrm{PD}$ & 100.0 & 8 & 0 & 0 & 0 & 0 & 0 & 0 \\
\hline $\mathrm{RD}$ & 77.8 & 14 & 16.7 & 3 & 5.6 & 1 & 0 & 0 \\
\hline SC & 0 & 0 & 25.0 & 3 & 25.0 & 3 & 50.0 & 6 \\
\hline
\end{tabular}

p Value <0.05, PD: Papillary Dermis, RD: Reticular Dermis, SC: Subcutaneous Tissue

0: No Staining, 1+: 1-25\%,2+: 26-50\%, 3+:51-100\% Positivity

Table II: CXCR4 distribution in basal cell carcinoma subtypes and squamous cell carcinomas

\begin{tabular}{|c|c|c|c|c|c|}
\hline \multirow{3}{*}{ BCC Subtypes, SCC } & \multicolumn{4}{|c|}{ CXCR4 } & \multirow{3}{*}{ p value } \\
\hline & \multicolumn{2}{|l|}{$(0,+1)$} & \multicolumn{2}{|l|}{$(2+, 3+)$} & \\
\hline & Number of patients (n) & $\%$ & Number of patients (n) & $\%$ & \\
\hline$\dot{\mathrm{I}}(\mathrm{BCC})$ & 1 & 14.3 & 6 & 85.7 & \multirow{4}{*}{$<0.05$} \\
\hline $\mathrm{MN}(\mathrm{BCC})$ & 3 & 75.0 & 1 & 25.0 & \\
\hline $\mathrm{N}(\mathrm{BCC})$ & 22 & 81.5 & 5 & 18.5 & \\
\hline SCC & 11 & 45.8 & 13 & 54.2 & \\
\hline
\end{tabular}

I: Infiltrative Subtype, MN: Multinodular Subtype, N: Nodular Subtype, SCC: Squamous Cell Carcinoma, BCC: Basal Cell Carcinoma

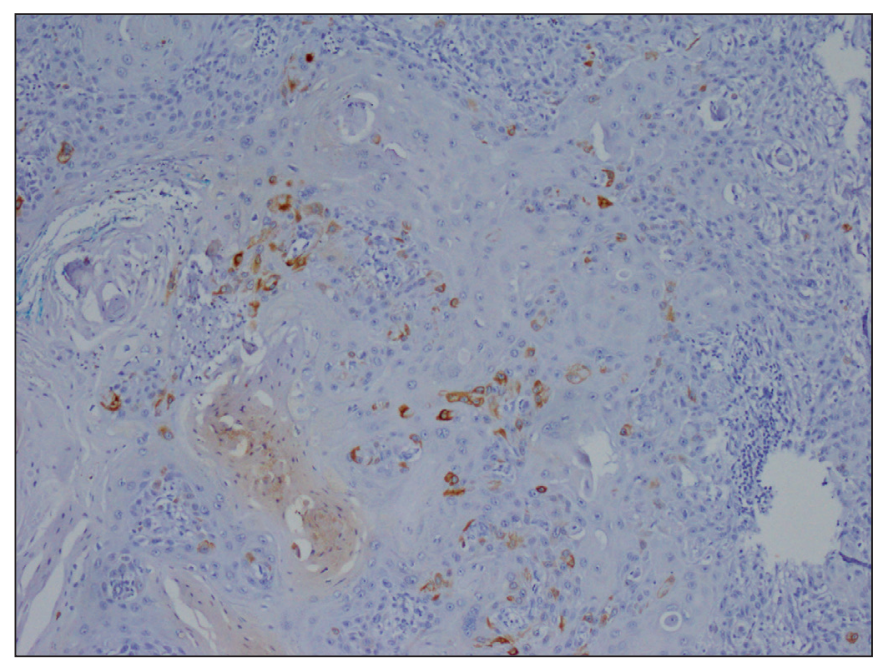

Figure 3: Squamous cell carcinoma, 1+ staining (CXCR-4; x40).

$81.5 \%$ and strong positivity in only $20.0 \%$ (Table II). These differences were statistically significant $(\mathrm{p}<0.05)$.

When the relationship between depth of invasion and CXCR-4 staining characteristics were evaluated in both BCC and SCC, cases with papillary dermis invasion showed absent or poor staining $(0,1+)$ in $85.7 \%$, and strong $(2+$,

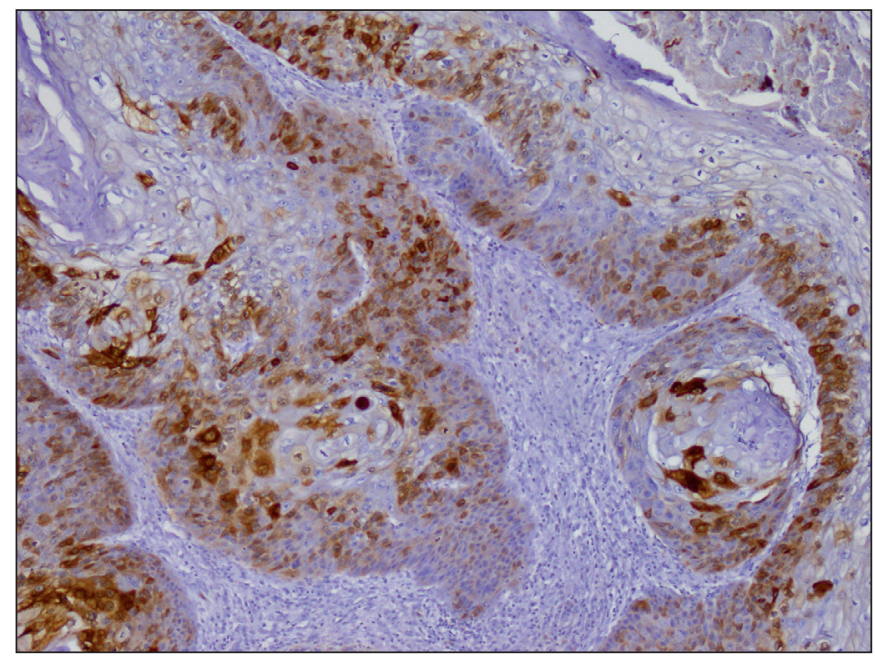

Figure 4: Squamous cell carcinoma, 3+ staining (CXCR-4; x100).

$3+$ ) staining in $14.3 \%$. Among cases with reticular dermis invasion, $71.4 \%$ either did not show any staining or poorly stained; whereas, $28.6 \%$ were strongly stained. In those with fat and deeper tissue invasion, the rate of poor staining was $25.0 \%$, and strong staining $75 \%$ (Table III). The results were statistically significant $(\mathrm{p}<0.05)$. 
Table III: Relationship between invasion depth and CXCR-4

\begin{tabular}{|l|c|c|c|c|c|}
\hline \multirow{2}{*}{ Invasion depth } & \multicolumn{4}{|c|}{ CXCR-4 } & \multirow{2}{*}{ p value } \\
\cline { 2 - 5 } & Number of patients (n) & \% & Number of patients (n) & \% & \multirow{2}{*}{$<0.05$} \\
\hline PD & 12 & 85.7 & 2 & 28.6 & \multirow{2}{*}{} \\
\hline RD & 20 & 71.4 & 8 & 75.0 & \\
\hline SC & 5 & 25.0 & 15 & & \\
\hline
\end{tabular}

PD: Papillary Dermis, RD: Reticular Dermis, SC: Subcutaneous Tissue

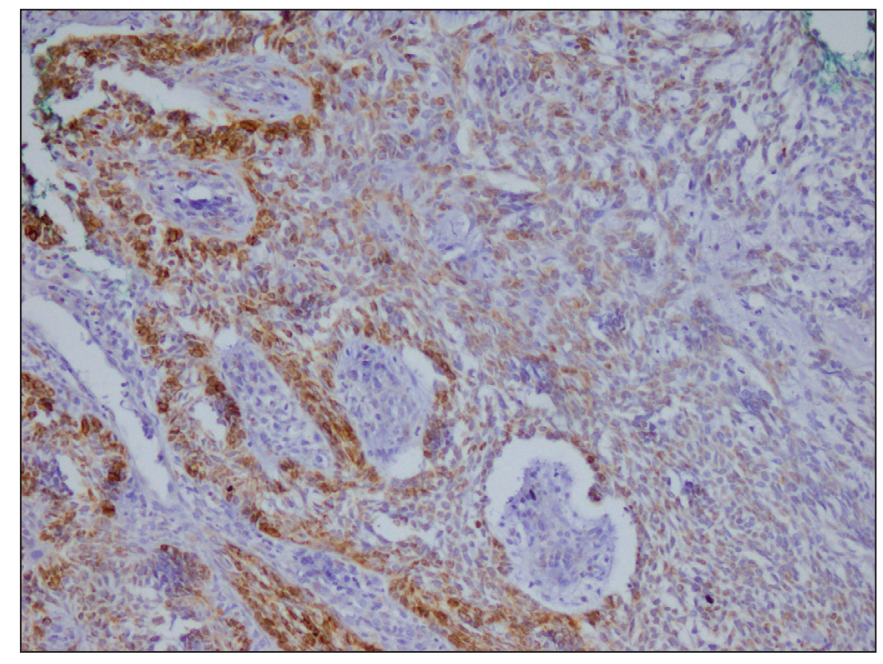

Figure 5: Basal cell carcinoma, 3+ staining (CXCR-4; x100).

Furthermore, there was no correlation between the age and CXCR-4 as well as COX-2 staining properties according to partial correlation test when the tumor type and BCC subtypes were sanctioned. A strongly positive correlation was observed between COX-2 staining properties and invasion. Similarly, a moderately positive correlation was observed between CXCR-4 staining and degree of invasion. A strongly positive correlation was also found between CXCR-4 and COX-2 (r: 0,725).

\section{DISCUSSION}

BCC and SCC are the two most common types of nonmelanoma skin carcinomas. UV light exposure plays an important role in the pathogenesis of both tumors. BCC is a localized disease and rarely metastasizes while SCC has the potential to metastasize (2).

Chemokine receptor expression in a malignant cell is associated with increased proliferation and cell motility. This results in tumor growth and metastasis $(7,11)$. In a study of 19 malignant melanoma cases, Toyozav et al. found CXCR-4 expression to be associated with tumor aggressiveness and poor prognosis (11).
Katayama et al. discovered that CXCR-4 expressing cells have high proliferation and migration capability in a study they conducted on head and neck SCCs. Furthermore, they also discovered that CXCR-4 expression decreased together with cellular proliferation and migration following treatment with IFN-alpha. Additionally, when multivariate analysis was conducted, CXCR-4 positivity emerged as an independent factor in tumor-specific mortality (17). Previous studies conducted on BCC showed CXCR4 expression to have a role in BCC tumorigenesis and angiogenesis (6). Chu et al. reported SDF-1 $\alpha /$ CXCR4 to be an important factor for BCC invasiveness (4).

We found CXCR-4 expression to be significantly increased in basal cell carcinoma, especially in the infiltrative subtype. In addition, a high rate of CXCR-4 positivity was found in squamous cell carcinomas. The increased CXCR-4 positivity with increasing invasiveness for both tumor types is important in identifying tumor aggressiveness.

We found the CXCR-4 expression rate to be higher $(2+, 3+)$ in SCC than BCC. Our finding suggests that SCC may have a higher metastatic potential when compared to BCC.

Another molecule playing a role in skin carcinogenesis is COX-2. Studies have shown that COX-2 expression stimulates cell division, angiogenesis, and inhibits apoptosis in neoplastic process $(7,8)$.

In 1999, Petland et al. found increased COX-2 expression in UV-induced skin tumors; conversely, decreased new tumor formation was demonstrated when a selective COX2 inhibitor was administered (18). Another study on oral SCC cases showed that the majority of COX-2-positive tumors showed cervical lymph node metastasis and tumors with low COX-2 expression responded better to chemoradiotherapy (19).

Yalcin et al. examined COX-2 and p53 expression in BCC, actinic keratosis and SCC. They discovered that no significant difference existed between aggressive and non-aggressive $\mathrm{BBC}$ cases in terms of COX-2 expression. 
However, the positivity rate was higher in SCC than BCC cases (3). Conversely, in our study, COX-2 expression was significantly higher in the aggressive subtypes of BCC than non-aggressive ones and the findings were statistically significant. Furthermore, COX-2 expression became more pronounced as invasion depth increased. Our higher degree of $(2+, 3+)$ COX-2 positivity in squamous may be cell carcinomas, compared to basal cell carcinomas indicates that this molecule may be important in terms of tumor aggressiveness and poor prognosis.

In conclusion, we found that aggressiveness in UV-induced skin tumors, namely BCC and SCC increased as COX-2 and CXCR-4 expression increased. We did not come across any study in the literature where these two markers, which can easily be applied immunohistochemically on a routine basis, were evaluated together in both BCC and SCC. Our study indicates that targeted treatments to inhibit CXCR4 and COX-2 can be useful for both tumors. We also demonstrated significantly positive correlation between these two molecular markers. Henceforth, we feel that there may also be a corresponding relationship in the process of carcinogenesis. Our findings may be instrumental for a genetically based study on a larger series of patients.

\section{REFERENCES}

1. Jemal A, Murray T, Ward E, Samuels A, Tiwari RC, Ghafoor A, Feuer EJ, Thun MJ. Cancer statistics, 2005. CA Cancer J Clin. 2005; 55:10-30.

2. Basile J, Thiers B, Maize J Sr, Lathers DM. Chemokine receptor expression in non-melanoma skin cancer. J Cutan Pathol. 2008;35:623-9.

3. Karagece Yalcin U, Seckin S. The expression of p53 and COX2 in basal cell carcinoma, squamous cell carcinoma and actinic keratosis cases. Turk Patoloji Derg. 2012;28:119-27.

4. Chu CY, Cha ST, Chang CC, Hsiao CH, Tan CT, Lu YC, Jee SH, Kuo ML. Involvement of matrix metalloproteinase-13 in stromalcell-derived factor 1 alpha-directed invasion of human basal cell carcinoma cells. Oncogene. 2007; 12;26:2491-501.

5. Wang J, Xi L, Hunt JL, Gooding W, Whiteside TL, Chen Z, Godfrey TE, Ferris RL. Expression pattern of chemokine receptor 6 (CCR6) and CCR7 in squamous cell carcinoma of the head and neck identifies a novel metastatic phenotype. Cancer Res. 2004; 64:1861-6.

6. Chen GS, Yu HS, Lan CC, Chow KC, Lin TY, Kok LF, Lu MP, Liu CH, Wu MT. CXC chemokine receptor CXCR4 expression enhances tumorigenesis and angiogenesis of basal cell carcinoma. Br J Dermatol. 2006;154:910-8.
7. Chu CY, Cha ST, Lin WC, Lu PH, Tan CT, Chang CC, Lin BR, Jee SH, Kuo ML. Stromal cell-derived factor-1alpha (SDF-1alpha/ CXCL12)-enhanced angiogenesis of human basal cell carcinoma cells involves ERK1/2-NF-kappaB/interleukin-6 pathway. Carcinogenesis. 2009;30:205-13.

8. Uchida D, Onoue T, Kuribayashi N, Tomizuka Y, Tamatani T, Nagai H, Miyamoto Y. Blockade of CXCR4 in oral squamous cell carcinoma inhibits lymph node metastases. Eur J Cancer. 2011;47:452-9.

9. Wald O, Shapira OM, Izhar U. CXCR4/CXCL12 axis in non small cell lung cancer (NSCLC) pathologic roles and therapeutic potential. Theranostics. 2013;3:26-33. PMID: 23382783

10. Mukherjee D, Zhao J. The Role of chemokine receptor CXCR4 in breast cancer metastasis. Am J Cancer Res. 2013;3:46-57.

11. Toyozawa S, Kaminaka C, Furukawa F, Nakamura Y, Matsunaka $\mathrm{H}$, Yamamoto Y. Chemokine receptor CXCR4 is a novel marker for the progression of cutaneous malignant melanomas. Acta Histochem Cytochem. 2012;45:293-9.

12. Sciaccaluga M, D’Alessandro G, Pagani F, Ferrara G, Lopez N, Warr T, Gorello P, Porzia A, Mainiero F, Santoro A, Esposito V, Cantore G, Castigli E, Limatola C. Functional cross talk between CXCR4 and PDGFR on glioblastoma cells is essential for migration. PLoS One. 2013;8:e73426.

13. Ohira S, Sasaki M, Harada K, Sato Y, Zen Y, Isse K, Kozaka K, Ishikawa A, Oda K, Nimura Y, Nakanuma Y. Possible regulation of migration of intrahepatic cholangiocarcinoma cells by interaction of CXCR4 expressed in carcinoma cells with tumor necrosis factor-alpha and stromal-derived factor-1 released in stroma. Am J Pathol. 2006;168:1155-68.

14. Shirahama T, Sakakura C. Overexpression of cyclooxygenase- 2 in squamous cell carcinoma of the urinary bladder. Clin Cancer Res. 2001;7(3):558-61.

15. Fosslien E. Molecular pathology of cyclooxygenase-2 in neoplasia. Ann Clin Lab Sci. 2000;30:3-21.

16. Zhan $\mathrm{H}$, Zheng $\mathrm{H}$. The role of topical cyclo-oxygenase-2 inhibitors in skin cancer: Treatment and prevention. Am J Clin Dermatol. 2007;8:195-200.

17. Katayama A, Ogino T, Bandoh N, Nonaka S, Harabuchi Y. Expression of CXCR4 and its down-regulation by IFN-gamma in head and neck squamous cell carcinoma. Clin Cancer Res. 2005;11:2937-46.

18. Pentland AP, Schoggins JW, Scott GA, Khan KN, Han R. Reduction of UV-induced skin tumors in hairless mice by selective COX-2 inhibition. Carcinogenesis. 1999; 20:1939-44.

19. Mohammad S, Ram H, Gupta PN, Husain N, Bhatt ML. Overexpression of COX-2 in oral squamous cell carcinoma patients undergoing chemoradiotherapy. Natl J Maxillofac Surg. 2011;2:17-21. 